\title{
Behandlingspraksis ved primær hyperparatyreoidisme
}

\begin{abstract}
Sammendrag
Bakgrunn. En studie viste betydelige regionale forskjeller i behandlingen av primær hyperparatyreoidisme i Norge. Det er uenighet om hvilke pasienter som har nytte av operasjon. Vi ønsket å undersøke synspunkter på behandlingsindikasjon for pasienter med primær hyperparatyreoidisme hos norske endokrinkirurger og et utvalg endokrinologer.
\end{abstract}

Materiale og metode. Et spørreskjema om praksis for utredning, indikasjonsvurdering og behandling av pasienter med primær hyperparatyreoidisme ble sendt til ansvarlig overlege ved de kirurgiske avdelinger som utførte parathyreoideakirurgi i 2005. Skjemaet ble også sendt til endokrinologer ved disse sykehusene.

Resultater. Det ble i 2006 utført 415 inngrep på parathyreoidea ved 17 sykehus i Norge, med en median på 18 inngrep per sykehus. Til sammen 46 kirurger opererte selvstendig på parathyreoidea, median to kirurger per sykehus. Det var forskjeller sykehusene imellom når det gjaldt preoperativ diagnostikk og vurdering av operasjonsindikasjoner ved primær hyperparatyreoidisme, men disse forskjellene sammenfalt ikke tydelig med de fylkesvise operasjonsfrekvensene. Det var godt samsvar mellom kirurgers og endokrinologers vurdering av operasjonsindikasjoner ved primær hyperparatyreoidisme, men verken kirurger eller endokrinologer fulgte konsekvent de foreslåtte internasjonale retningslinjene for hvilke pasienter med primær hyperparatyreoidisme som bør tilbys kirurgi.

Pasientene ved de sykehusene der det opereres hyppigst, var i stor grad initialt diagnostisert ved en kirurgisk avdeling

Fortolkning. Vår undersøkelse av behandlingspraksis har ikke avslørt vesentlige forskjeller som kan forklare de store fylkesvise variasjonene i operasjonsfrekvens.

\section{Haakon M. Lindekleiv \\ Jan Due \\ jan.due@unn.no}

Avdeling for urologi og endokrin kirurgi

Universitetssykehuset Nord-Norge

9038 Tromsø

\section{Johan Svartberg}

Endokrinologisk seksjon

Medisinsk avdeling

Universitetssykehuset Nord-Norge

og

Institutt for klinisk medisin

Det medisinske fakultet

Universitetet i Troms $\varnothing$

\section{Jan Erik Varhaug}

Seksjon for bryst- og endokrin kirurgi

Kirurgisk avdeling

Haukeland universitetssykehus

og

Institutt for kirurgiske fag

Universitetet i Bergen

Hyperparatyreoidisme er en fellesbetegnelse på sykdommer som medfører økt nivå av parathyreoideahormon (PTH) i blodet. Dette hormonet styrer kalsiumbalansen i kroppen, og normalt synker PTH-produksjonen ved økende nivå av kalsium. Når en eller flere kjertler er forstørret og produserer for mye parathyreoideahormon ved høyt kalsiumnivå, kalles sykdommen primær hyperparatyreoidisme (1).

Diagnosen stilles ved påvisning av simultant forhøyet kalsium- og PTH-nivå i blodet. De klassiske symptomene på primær hyperparatyreoidisme inkluderer nyrestein, beinskjørhet og obstipasjon. I tillegg rapporterer mange pasienter symptomer som blant annet nedstemthet, at man lett blir trett, søvnproblemer og konsentrasjonsvansker (2). At kirurgisk behandling har effekt på de klassiske symptomene er veldokumentert, men fordelene med kirurgi hos pasienter uten de klassiske symptomene er omdiskutert $(3,4)$. Retningslinjer for operasjonsindikasjoner ble vedtatt av en tverrfaglig internasjonal ekspertgruppe på en konsensuskonferanse ved National Institutes of Health i 1990 og revidert i 2002 (ramme 1) (5). Disse er foreslått som utgangspunkt for behandlingen av norske pasienter, uten at det er blitt enighet om dette (6)

I Norge har antall inngrep på parathyreoidea økt betydelig siden 1999, men det er store forskjeller i operasjonsfrekvens fylkene imellom (7). Vi ønsket derfor å undersøke om det foreligger ulike synspunkter på indikasjonen for kirurgisk behandling hos norske kirurger og et utvalg endokrinologer.

\section{Materiale og metode}

Et spørreskjema basert på de amerikanske retningslinjene om praksis for utredning, indikasjonsvurdering og behandling av pasienter med primær hyperparatyreoidisme ble i november 2007 sendt til ansvarlig overlege ved de 18 kirurgiske avdelingene der det ble utført parathyreoideakirurgi i 2005. Skjemaet var firedelt. Den første delen angikk organiseringen av parathyreoideakirurgien, antall kirurger som opererte samt antall inngrep utført i 2006. I del 2 skulle det gjøres rede for hvordan pasientene ble utredet preoperativt samt hvordan inngrepet ble utført. I del 3 ble respondentene bedt om å ta stilling til innholdet $\mathrm{i}$ de amerikanske konsensusretningslinjene for kirurgi. I del 4 skulle man oppgi hvilke forhold som ble vektlagt ved vurdering av operasjon. Det fantes endokrinolog ved 14 av sykehusene, og spørreskjemaets del 3 og del 4 ble sendt til disse.

All databearbeiding er utført i SPSS versjon 14.0. Det er ikke gjort sammenliknende statistiske beregninger, da tallet på respondenter samlet var lavt. Enkelte av spørreskjemaene var ikke fullstendig utfylt - dette forklarer variasjonen i antall svar på de forskjellige spørsmålene.

\section{Resultater}

Ved 17 sykehus ble det fortsatt operert på parathyreoidea i 2007. Vår henvendelse ble besvart av alle de kirurgiske avdelingene. 12 av endokrinologene $(86 \%)$ besvarte spørreskjemaet.

Det ble i 2006 utført 415 inngrep på parathyreoidea i Norge - $368(89 \%)$ ekstirpasjoner av lesjon i parathyreoidea, 46 (11\%) subtotale paratyreoidektomier og én total paratyreoidektomi - med en median på 18 inngrep per sykehus (spredning 8-68 inngrep). Til sammen 46 kirurger opererte selvstendig på parathyreoidea ved de nevnte avdelingene, median to per sykehus (spredning $1-7$ kirurger). Ved 11 sykehus (67\%) ble

\section{Hovedbudskap}

- Det eksisterer fylkesvise forskjeller i preoperativ diagnostikk og behandling av pasienter med hyperparatyreoidisme

- Disse forskjellene sammenfaller ikke med de betydelige fylkesmessige forskjellene i operasjonsfrekvens 
Tabell 1 Spørsmål: Av henviste pasienter med følgende symptomer/situasjoner, i hvilken grad tilbyr/henviser dere til operasjon?

\begin{tabular}{|c|c|c|c|c|c|c|}
\hline & \multicolumn{3}{|c|}{ Kirurger } & \multicolumn{3}{|c|}{ Endokrinologer } \\
\hline & Rutinemessig & Av og til & Sjelden/aldri & Rutinemessig & Av og til & Sjelden/aldri \\
\hline & Antall (\%) & Antall (\%) & Antall (\%) & Antall (\%) & Antall (\%) & Antall (\%) \\
\hline Nyrestein, obstipasjon, beinskjørhet & $16(100)$ & & & $8(67)$ & 4 (33) & \\
\hline S-Ca $>2,85$ uten symptomer & $13(76)$ & $4(24)$ & & $8(67)$ & 4 (33) & \\
\hline $\mathrm{S}-\mathrm{Ca} \leq 2,85$ uten symptomer, alder $>50$ år & $1(6)$ & $13(76)$ & $3(18)$ & 1 (8) & $5(42)$ & $6(50)$ \\
\hline $\mathrm{S}-\mathrm{Ca} \leq 2,85$ uten symptomer, alder $<50$ år & $8(47)$ & 9 (53) & & $7(58)$ & 4 (33) & 1 (8) \\
\hline S-Ca $\leq 2,85$ med ikke-klassiske symptomer & $7(41)$ & 10 (59) & & $2(17)$ & 9 (75) & $1(8)$ \\
\hline Kalsium i øvre normalområde og PTH simultant forhøyet & & $8(50)$ & $8(50)$ & & $5(45)$ & $6(55)$ \\
\hline
\end{tabular}

inngrepet utført ved en spesialisert bryst- og endokrinkirurgisk avdeling/seksjon.

Hvordan pasientene var oppdaget, varierte sterkt mellom sykehusene. I gjennomsnitt var $13 \%$ av pasientene initialt avdekket ved egen eller annen kirurgisk avdeling (variasjon $0-90 \%$ ), $51 \%$ var avdekket hos ind-

remedisiner/endokrinolog (variasjon 10 $100 \%$ ) og $36 \%$ var avdekket primært hos allmennlege (variasjon 0-80\%).

Hvordan kirurg og endokrinolog vurderte operasjonskriteriene ut fra de foreslåtte retningslinjene for kirurgi er vist $i$ tabell 1 , forskjeller i preoperativ utredning i tabell 2 .

Tabell 2 Spørsmål: I hvilken grad utredes pasientene preoperativt med følgende undersøkelser?

\begin{tabular}{lccc} 
& \multicolumn{3}{c}{ Kirurger } \\
\cline { 2 - 4 } & Rutinemessig & Avog til & Sjelden/aldri \\
& Antall $(\%)$ & Antall $(\%)$ & Antall $(\%)$ \\
Planar scintigrafi & $12(75)$ & $2(12,5)$ & $2(12,5)$ \\
SPECT (enfotonstomografi) scintigrafi & $7(41)$ & $5(29)$ & $5(29)$ \\
Ultralyd & $9(56)$ & $5(31)$ & $2(13)$ \\
Måling av & & & \\
Totalt kalsiumnivå & $17(100)$ & & \\
lonisert kalsium & $16(94)$ & $1(6)$ & $4(24)$ \\
Beintetthet & $6(35)$ & $7(41)$ & $5(30)$ \\
D-vitamin & $6(35)$ & $6(35)$ &
\end{tabular}

Respondentene ble i tillegg spurt om i hvilken grad de vektla et utvalg forhold ved vurdering av operasjon (tab 3 ).

Ved samtlige avdelinger ble halseksplorasjon utført i narkose, mens det ved fire avdelinger $(23 \%)$ ble gjort minimalt invasiv kirurgi i lokalbedøvelse. Ved 15 avdelinger $(88 \%)$ ble det utført intraoperativ hurtigmåling av parathyreoideahormon.

Når det gjelder de fylkesvise forskjellene i operasjonsfrekvens, ble det ikke observert større forskjeller i vurderingen av operasjonskriterier mellom de fire sykehusene som behandlet pasienter i de fem fylkene med høyest operasjonsfrekvens (Østfold, Vestfold, Telemark, Rogaland og Troms) og de seks sykehusene som behandlet pasienter fra de fem fylkene med lavest frekvens (Akershus, Oslo, Oppland, Sogn og Fjordane, Buskerud) (tab 4). Pasienter med primær hyperparatyreoidisme i Vestfold blir for tiden operert i Telemark (N. Podhorny, personlig meddelelse). Andelen pasienter som initialt var oppdaget ved egen eller en annen kirurgisk avdeling, var høyere i fylkene med

Tabell 3 Spørsmål: I hvilken grad vektlegges følgende ved spørsmål om indikasjon for operasjon?

\begin{tabular}{|c|c|c|c|c|c|c|}
\hline & \multicolumn{3}{|c|}{ Kirurger } & \multicolumn{3}{|c|}{ Endokrinologer } \\
\hline & Sterkt & Delvis & Ikke & Sterkt & Delvis & Ikke \\
\hline & Antall (\%) & Antall (\%) & Antall (\%) & Antall (\%) & Antall (\%) & Antall (\%) \\
\hline Verdi av total-Ca alene & $5(36)$ & $4(28)$ & $5(36)$ & $6(50)$ & $5(42)$ & $1(8)$ \\
\hline Verdi av ionisert Ca alene & $8(50)$ & $5(31)$ & $3(19)$ & $6(50)$ & $5(42)$ & $1(8)$ \\
\hline Verdi av PTH alene & $4(25)$ & $8(50)$ & $4(25)$ & $1(8)$ & $5(42)$ & $6(50)$ \\
\hline $\mathrm{Ca}+\mathrm{PTH}$, samlet vurdering & $17(100)$ & & & $10(84)$ & $1(8)$ & $1(8)$ \\
\hline Annen biokjemi (D-vitamin, Ca i urin, fosfat) & $3(18)$ & $13(76)$ & $1(6)$ & 4 (37) & $6(54)$ & $1(9)$ \\
\hline \multicolumn{7}{|l|}{ Symptomer } \\
\hline Nyrestein & $12(75)$ & $4(25)$ & & $11(92)$ & $1(8)$ & \\
\hline Obstipasjon & $3(18)$ & 10 (59) & 4 (23) & 10 (82) & $2(16)$ & \\
\hline Beinskjørhet & $13(76)$ & $4(24)$ & & 9 (75) & $3(25)$ & \\
\hline Nedstemthet & $2(12)$ & $13(76)$ & $2(12)$ & & $9(90)$ & $1(10)$ \\
\hline Kognitiv svikt & $4(24)$ & $11(64)$ & $2(12)$ & $1(9)$ & 9 (82) & $1(9)$ \\
\hline$\emptyset k t$ muskulær trettbarhet & $2(12)$ & $15(88)$ & & $2(17)$ & 9 (75) & $1(8)$ \\
\hline Kardiovaskulære & $1(6)$ & $12(75)$ & $3(19)$ & $1(8)$ & $7(58)$ & $4(34)$ \\
\hline Gastrointestinale & $1(6)$ & $8(47)$ & $8(47)$ & $1(8)$ & $8(67)$ & $3(25)$ \\
\hline Alder & $4(25)$ & 11 (69) & $1(6)$ & 4 (33) & $8(67)$ & \\
\hline
\end{tabular}




\section{Ramme 1}

\section{Tidligere foreslåtte retningslinjer for operasjonsindikasjon}
- $\mathrm{S}-\mathrm{Ca}>2,85 \mathrm{mmol} / \mathrm{l}$
- Pasienter $<50$ år
- Urinveiskonkrementer
- Redusert nyrefunksjon
- Beinskjørhet

høyest operasjonsfrekvens enn i fylkene med lavest ( $38 \%$ mot $2 \%)$.

\section{Diskusjon}

Hovedfunnene i denne studien er at det er forskjeller sykehusene imellom når det gjelder preoperativ diagnostikk og vurdering av operasjonsindikasjoner ved primær hyperparatyreoidisme, men at disse forskjellene ikke tydelig sammenfaller med de fylkesvise operasjonsfrekvensene. Det er godt samsvar mellom kirurgers og endokrinologers vurdering av operasjonsindikasjoner ved primær hyperparatyreoidisme, men verken kirurger eller endokrinologer følger konsekvent de foreslåtte retningslinjene for hvilke pasienter som bør tilbys kirurgi. Parathyreoideakirurgi foregår i dag hovedsakelig ved avdelinger viet bryst- og endokrinkirurgi. Det er forskjeller sykehusene imellom når det gjelder i hvilken grad nye teknikker som preoperativ lokalisering med enfotonstomografi (SPECT) og minimalt invasiv kirurgi i lokalbedøvelse er tatt i bruk.

Denne studiens styrke er den høye svarprosenten fra de kirurgiske og endokrinologiske avdelingene. En begrensning ved studien er at svaralternativene var tredelt (rutinemessig, av og til, sjelden/aldri), noe som kan ha bidratt til å maskere mindre forskjeller mellom avdelingene.

\section{Forskjeller mellom kirurger og endokrinologer}

Selv om vurderingen av operasjonsindikasjoner hos kirurgene og endokrinologene $\mathrm{i}$ stor grad er sammenfallende, er det enkelte forskjeller. Halvparten av kirurgene tilbød regelmessig operasjon til pasienter med serum-kalsium $\leq 2,85 \mathrm{mmol} / \mathrm{l}$ og ikke-klassiske symptomer - endokrinologene var mer restriktive. Alle kirurgene anså de klassiske symptomene på primær hyperparatyreoidisme som absolutte operasjonsindikasjoner, mens kun åtte av de 12 endokrinologene rutinemessig henviste pasienter med disse symptomene til operasjon. Dette er overraskende, tatt i betraktning at effekten av kirurgi ved hyperparatyreoidisme på nyresteindanning, tendens til beinskjørhet og obstipasjon er godt dokumentert (8). Dog la en firedel av kirurgene bare delvis vekt på nyresteinsymptomer ved operasjonsvurderingen. Forskjellene mellom kirurger og endokrinologer når det gjelder vektlegging av obstipasjonssymptomer er også påfallende.

\section{Årsaker til de regionale forskjellene i operasjonsfrekvens}

Vi finner i denne undersøkelsen ingen store forskjeller mellom indikasjonsvurderingen ved sykehus i fylker der det opereres hyppigst og vurderingen ved sykehus i fylker der det opereres sjeldnest på parathyreoidea. Dette kan muligens være betinget $i$ at våre svaralternativer har vært for grove, skjønt man kan få inntrykk av at pasienter $<50$ år uten symptomer i større grad rutinemessig ble operert i fylkene med høyest operasjonsfrekvens.

Det er interessant at pasientene i fylkene med høyest operasjonsfrekvens i større grad var initialt avdekket ved egen eller annen kirurgisk avdeling. En mulig forklaring på de fylkesmessige forskjellene er at innstillingen til og interessen for sykdommen varierer mellom kirurgene, så mye kommer an på hva den enkelte vektlegger og hvordan kunnskapen benyttes. Dette siste har vi imidlertid ikke undersøkt.

\section{Er det behov for nasjonale retningslinjer?}

Våre data viser forskjeller i vurderingen av indikasjoner for kirurgi mellom sykehus, selv om denne ikke er sterkt assosiert med de fylkesvise operasjonsfrekvensene. At pasienter enkelte steder i Norge blir henvist til og tilbudt behandling for primær hyperparatyreoidisme og andre steder ikke, skyldes nok at det mangler godt dokumenterte kriterier for kirurgi ved tilstanden, spesielt ved såkalt asymptomatisk hyperparatyreoidisme $(3,4)$.
Eksistens av anbefalte kriterier er imidlertid ikke ensbetydende med utjevning av regionale variasjoner. To studier har vist at de amerikanske retningslinjene for kirurgi ved primær hyperparatyreoidisme $\mathrm{i}$ begrenset grad etterleves av endokrinologer og endokrinkirurger i USA $(9,10)$.

\section{Konklusjon}

Vår undersøkelse har ikke avslørt tydelige forskjeller som kan forklare de betydelige fylkesvise variasjonene i operasjonsfrekvens.

Vi takker kirurgene og endokrinologene som besvarte spørreskjemaet.

\section{Oppgitte interessekonflikter: Ingen}

\section{Litteratur}

1. Almdahl S, Due J. Primær hyperparatyreoidisme. Tidsskr Nor Lægeforen 1987: 107: 1873-4.

2. Mack LA, Pasieka JL. Asymptomatic primary hyperparathyroidism: a surgical perspective. Surg Clin North Am 2004; 84: 803-16.

3. Ambrogini E, Cetani F, Cianferotti L et al. Surgery or surveillance for mild asymptomatic primary hyperparathyroidism: a prospective, randomized clinical trial. J Clin Endocrinol Metab 2007; 92 : 3114-21

4. Bollerslev J, Jansson S, Mollerup CL et al. Medical observation, compared with parathyroidectomy. for asymptomatic primary hyperparathyroidism: a prospective, randomized trial. J Clin Endocrinol Metab 2007; 92: 1687-92.

5. Bilezikian JP. Potts JT jr., Fuleihan Gel-H et al. Summary statement from a workshop on asymptomatic primary hyperparathyroidism: a perspec tive for the 21st century. J Bone Miner Res 2002; 17 (suppl 2): N2-11.

6. Varhaug JE. Primær hyperparatyreoidisme - en underdiagnostisert sykdom. Tidsskr Nor Lægeforen 2000; 120: 2376.

7. Lindekleiv H, Due J. Parathyreoideakirurgi i Norge 1999-2005. Tidsskr Nor Lægeforen 2007; 127 $1181-4$.

8. Silverberg SJ, Shane E, Jacobs TP et al. A 10-year prospective study of primary hyperparathyroidism with or without parathyroid surgery. N Engl J Med 1999: 341: 1249-55.

9. Mahadevia PJ Sosa JA, Levine MA et al. Clinical management of primary hyperparathyroidism and thresholds for surgical referral: a national study examining concordance between practice patterns and consensus panel recommendations. Endocr Pract 2003: 9. 494-503

10. Kouvaraki MA, Greer M, Sharma S et al. Indications for operative intervention in patients with asymptomatic primary hyperparathyroidism: practice patterns of endocrine surgery. Surgery 2006; 139: $527-34$.

Manuskriptet ble mottatt 3.4. 2008 og godkjent 20.10. 2008. Medisinsk redaktør Kjetil Søreide.

Tabell 4 Spørsmål: I hvilken grad vektlegges følgende ved spørsmål om indikasjon for operasjonen?

\begin{tabular}{|c|c|c|c|c|c|c|}
\hline & \multicolumn{3}{|c|}{$\begin{array}{l}\text { Sykehus i de fem fylkene med høyest } \\
\text { operasjonsfrekvens }\end{array}$} & \multicolumn{3}{|c|}{$\begin{array}{c}\text { Sykehus i de fem fylkene med lavest } \\
\text { operasjonsfrekvens }\end{array}$} \\
\hline & Rutinemessig & Av og til & Sjelden/aldri & Rutinemessig & Av og til & Sjelden/aldri \\
\hline Nyrestein, obstipasjon, beinskjørhet & 4 & & & 5 & & \\
\hline S-Ca > 2,85 uten symptomer & 3 & 1 & & 5 & 1 & \\
\hline S-Ca $<2,85$ uten symptomer, alder > 50 år & 1 & 3 & & & 4 & 2 \\
\hline S-Ca $<2,85$ uten symptomer, alder $<50$ år & 3 & 1 & & 1 & 5 & \\
\hline S-Ca $<2,85$ med ikke-klassiske symptomer & 2 & 2 & & 1 & 5 & \\
\hline Kalsium i øvre normalområde og PTH simultant forhøyet & & 3 & 1 & & 1 & 5 \\
\hline
\end{tabular}

